\title{
ERBB2 NP_004439.2:p.E321G
}

National Cancer Institute

\section{Source}

National Cancer Institute. ERBB2 NP 004439.2:p.E321G. NCI Thesaurus. Code C155309.

A change in the amino acid residue at position 321 in the receptor tyrosine-protein kinase erbB-2 protein where glutamic acid has been replaced by glycine. 